BULLETIN Bulletin hispanique

HISPANIQUE Université Michel de Montaigne Bordeaux

$120-2$ | 2018

Varia

\title{
Fecundaciones, infecciones, excitaciones extrañas: imágenes de la modernidad entre siglos
}

Fécondations, infections, excitations étranges : images de la Modernité d'un siècle à l'autre

Fecondations, infections, strange excitations: the images of Modernity from one century to the other

\section{Luis Caparrós Esperante}

\section{(2) OpenEdition}

\section{Journals}

Edición electrónica

URL: https://journals.openedition.org/bulletinhispanique/6762

DOI: 10.4000/bulletinhispanique.6762

ISSN: 1775-3821

\section{Editor}

Presses universitaires de Bordeaux

\section{Edición impresa}

Fecha de publicación: 10 diciembre 2018

Paginación: 489-504

ISBN: 979-10-300-0337-6

ISSN: 0007-4640

\section{Referencia electrónica}

Luis Caparrós Esperante, «Fecundaciones, infecciones, excitaciones extrañas: imágenes de la modernidad entre siglos», Bulletin hispanique [En línea], 120-2 | 2018, Publicado el 02 enero 2022, consultado el 08 enero 2022. URL: http://journals.openedition.org/bulletinhispanique/6762 ; DOI: https://doi.org/10.4000/bulletinhispanique.6762 


\title{
Fecundaciones, infecciones, excitaciones extrañas: imágenes de la modernidad entre siglos
}

\author{
Luis CAPARrós Esperante \\ Universidade da Coruña
}

\begin{abstract}
Fécondations, infections, excitations étranges: images de la Modernité d'un siècle à l'autre

Le titre résume quelques stratégies discursives sur la réception des nouveautés littéraires dans l'Espagne du XIX et il interroge les limites de la modernité à partir de la deuxième moitié du siècle. Il s'agit d'enquêter sur les signifiés cachés derrière le ton et les manières des discours casticistas des uns et des autres. L'objectif est de vérifier si le véritable problème se trouvait dans les " essences ", dans la contamination du langage ou à d'autres niveaux.
\end{abstract}

Mots-clés: modernité, infections littéraires, Casticismo.

El título resume algunas estrategias discursivas sobre la recepción de novedades literarias en la Espańa del XIX y apunta a los límites de la modernidad desde la segunda mitad. Interesa indagar en los significados agazapados bajo el tono y maneras de los discursos casticistas, de unos y de otros. El objetivo sería comprobar si el auténtico problema estaba en las esencias, en la contaminación del lenguaje o en otro plano.

Palabras clave: modernidad, infecciones literarias, Casticismo.

Fecondations, infections, strange excitations: the images of Modernity from one century to the other

The title summarizes some discursive strategies on the reception of literary developments in nineteenth-century Spain, as it points out the limits of modernity, from the second half of the century. The aim is to analyse the meanings hiding behind the tone and manner of casticista speeches, on both sides of the political scene. In this way, we will check if the real problem was essences, pollution in language or perhaps on another plane.

Keywords: Modernity, Literary Infections, Casticismo. 
«La vida intelectual de un pueblo necesita una excitación extraña que la fecunde» (Azorín).

$\mathrm{E}_{1}^{1}$ título resume algunas de las estrategias discursivas que acompañaron la recepción de novedades literarias en la España del XIX, en trance de «inventarse» como Estado-nación ${ }^{1}$. Frente a esta construcción, de signo liberal, reaccionaban los sectores del Antiguo Régimen, encastillados frente a lo nuevo. Unos y otros competirán por ocupar (por nacionalizar o por inmunizar en su caso) el espacio mítico de lo esencial español, lo llamado castizo. Sin embargo, como señaló Álvarez Junco, "la imagen de dudosamente espańolas perseguiría a las élites modernizadoras hasta bien entrado el siglo XX» (118), y este obstáculo al proceso nacionalizador es peculiaridad española. Propicia además que, en muchas ocasiones, las líneas entre ellos fuesen engañosas o cambiantes. «La derecha católica comenzó el siglo XIX repudiando la idea de nación y lo terminó en el nacional catolicismo» (Álvarez Junco 22). Persisten, con todo, diferencias sustanciales acerca del encaje con Europa o sobre la idea misma de modernidad, como veremos.

Si nos preguntamos hasta qué punto las novedades literarias y sus lenguajes contradecían las supuestas esencias de lo español aceptamos, de hecho, una falacia. Resultará más revelador indagar lo que enmascaran el tono y maneras de los discursos casticistas, vengan de donde vengan. Visto así, el problema no serían las esencias, sino ese factor agazapado de "lo moderno» y sus límites posibles. De hecho, ante las corrientes innovadoras no hallaremos un único patrón de comportamiento, ni siquiera en el campo conservador. Pondré dos ejemplos, para centrarme en el segundo. ¿Por qué se aplauden los préstamos italianos de Garcilaso o de Cervantes? ¿Por qué se niegan, en cambio, las novedades francesas llegadas hacia el final de siglo en las maletas de Rubén Darío?

\section{"A LA FRANCESA»}

Sin duda, el rechazo de las maletas de Darío tenía más que ver con su contenido que con su forma ${ }^{2}$. Hay novedades que se naturalizan de inmediato, sin necesidad de pasaporte. Sucede con el romanticismo conservador, que desde Böhl de Faber se ve como un revival del Siglo de Oro. Si se trata de

1. Hobsbawm utiliza el término «invención» para este proceso, a partir de «la comunidad lingüística y cultural, que fue una innovación del siglo XIX» (Hobsbawm 111) ligada al liberalismo.

2. Algo de esto fue señalado hace tiempo por Lily Litvak y luego ampliado en sucesivos estudios: «La violencia de esta respuesta revela que en realidad el modernismo intentaba llevar a cabo algo más importante: un cambio de fondo y no solo de forma, y presentaba una nueva escala de valores que iban más allá de la poesía» (Litvak 397). 
la novela realista, el realismo pasará a ser rasgo esencial y permanente de lo español, como sentencia Menéndez Pidal (Fox 1997: 97-109). Esto hace más sintomática la coincidencia entre el rechazo de ciertas formas foráneas y el inicio de la modernidad, que alcanza su momento expansivo a mediados del XIX.

Francia ocupa el lugar central por muchos motivos, a la sombra de 1808 y de las primeras polémicas del romanticismo (Carnero). Es la fuente principal de novedades. O de modernidad, si se prefiere. El baldón de afrancesados era político, pero se extenderá durante largo tiempo a la moderadísima Ilustración española. ¿Cómo ignorar que Francia era la cuna del filosofismo, la sensualidad y la revolución y, acabando el siglo, foco del naturalismo o de la chaise longue decadente?

Recordemos la Centinela contra Franceses (1808), de Capmany, quien soñaba una España convertida en isla. Más sintomático, para nuestro fin, es el Remedio y preservativo contra el mal francés de que adolece parte de la nación española, escrito por Manuel Freyre (1809). El mal francés, como no hará falta decir, era la sífilis. Comprobamos desde ahora cómo el léxico para describir la llegada de lenguajes foráneos tiende a lo patológico y lo sexual, incluso cuando se quiere neutro. Freyre fija además un catálogo de estereotipos. Los franceses siempre han sido «ligeros, frívolos, afeminados, voluptuosos, noveleros, mentirosos, engañadores, interesados, disimulados, pícaros, traidores, rebeldes, presumidos, dominantes, provocativos, pendencieros, inhumanos e impíos» (Freyre 4). Pues hoy, insiste, cuando ni siquiera profesan la religión cristiana, ¿qué esperaremos de una nación que ha "hollado con furor endemoniado, o a la francesa, la religión", y que "hacen pública y jactanciosamente, a la francesa, profesión de regicidas, ateos, bandidos y en una palabra, jacobinos?» (4).

Vayamos ya al final de siglo. El mote de «a la francesa» lo repetirá Pereda cuando ingresa en la Real Academia, en 1897, e increpa al «más obcecado modernista»:

A la francesa ... o a la inglesa, se vive hoy en la clásica tierra castellana, y se anda, y se legisla, y se viaja, y se piensa; a las horas que en Francia o en Inglaterra se sientan a comer nuestros próceres y gentes encopetadas; en francés se imprime la minuta de lo que van comiendo y hasta de los famosos vinos españoles que van bebiendo; [...] extranjera la lengua que a ratos se habla entre los satisfechos comensales; extranjera la decoración del resto de la casa, y extranjeros, en fin, han de ser los libros que lean en sus ratos de ocio las señoras que la habitan. (Pereda 17)

Si hablamos de creación, "ise puede construir con estos materiales extranjeros, y sin un milagro de Dios, una obra española, en el sentido en que debe tomarse esta palabra cuando se trata de obras de arte?» (18). No hace falta leer mucho para comprobar que el problema de fondo no está en la lengua, sino en otro plano menos formal que ideológico. El «modernista» a quien increpa el ultraconservador Pereda no es solo de «los tétricos de la negación y de la duda, que son los melenudos de ahora", sino que incluye a los naturalistas, a 
ese «intruso, desconsolador y, a menudo, mal oliente naturalismo» (19 y 20). El mote de «a la francesa» cubre así un siglo entero ${ }^{3}$.

Hagamos una última cata. En 1905, cuando ya el modernismo pierde filo o se toma medidas para el traje noventayochista, oímos aún a Emilio Ferrari predicar en la Academia contra las «deformaciones y extravíos morbosos que, transmitiéndose a las letras, ya que no con paralizar su progreso, amenazan con entorpecerle y retardarlo si no se ataja reciamente la influencia invasora del contagio» (Ferrari 12). Ferrari coincide con Pereda en que la epidemia tiene dos focos, el naturalista y el modernista, "manifestaciones todas de un verdadero libertinaje intelectual» (19):

Y lo singular es que de esta vorágine de ideas radicalmente incompatibles no sale fragor de batalla, sino más bien algazara de orgía, en la cual monstruosamente pactan y se ayuntan, recibiendo todas igual culto de unos mismos adeptos. De donde se ha originado en las ciencias lo que ahora se llama dilettantismo, linaje de corrupción o refinamiento intelectual que consiste en ver en todo un simple juego del espíritu, convirtiendo el austero amor del saber en estragamiento vicioso; y de donde ha nacido en las artes el denominado modernismo, que es la resurrección de todas las vejeces en el Josafat de la extravagancia. (Ferrari 15-16)

La gente está loca y los tiempos son extraños, pensarían muchos, pero allí quedaba flotando la sugerente alusión a la «algazara de orgía», con sus promesas de pactos y ayuntamientos.

\section{RESISTENCIA(s) A LA MODERNIDAD}

Quedaríamos en la anécdota si no encajamos estas periódicas alertas de infección dentro un marco más amplio, como es la dialéctica de la modernidad. No es cuestión de bandos o una vuelta más sobre los «antiguos y modernos». La modernidad se liga a los cambios históricos, según la define Habermas, entre otros ${ }^{4}$. Significa racionalismo, progreso y, por ańadidura, los valores revolucionarios que venían de 1789 , no sin contradicciones a medida que el propio desarrollo capitalista los va cuestionando. La modernidad, desde el medio siglo, irá tomando un carácter revulsivo, rebelde a las normas burguesas en las que al mismo tiempo se enmarca:

3. Mariano López aporta numerosos datos en el mismo sentido: «Nos explicamos: la crítica enemiga del naturalismo hace hincapié en la denuncia no sólo del carácter erótico, sino incluso impío y blasfemo de la nueva escuela. [...] Víctimas de una especie de nacionalismo hipertrófico y sectarismo endémico consideran como términos equivalentes inmoralidad e innovación literaria, sobre todo si viene ésta de Francia.» (López 63-64)

4. «En el curso del XIX emergió de este espíritu romántico la conciencia radicalizada de modernidad que se liberó de todos los vínculos históricos específicos. Este modernismo más reciente establece una oposición abstracta entre la tradición y el presente, y, en cierto sentido, todavía somos contemporáneos de esa clase de modernidad estética que apareció por primera vez a mediados del siglo pasado.» (Habermas 20-21) 
La modernidad se rebela contra las funciones normalizadoras de la tradición. La modernidad vive de la experiencia de rebelarse contra todo cuanto es normativo. Esta revuelta es una forma de neutralizar las pautas de moralidad y la utilidad. La conciencia estética representa continuamente un drama dialéctico entre el secreto y el escándalo público, le fascina el horror que acompaña al acto de profanar y, no obstante, siempre huye de los resultados triviales de la profanación. (Habermas 22)

A esta luz, es fácil interpretar las resistencias de Pereda como muestra de su nostalgia por modos de producción precapitalistas, cuyos códigos culturales sucumben bajo la lógica del desarrollo burgués 5 . Pero ¿̇irve esto para progresistas como Galdós o Clarín? ¿Y para la prueba de fuego del modernismo?

Pérez Galdós, por su defensa de las clases medias urbanas, es lo opuesto a Pereda, como no hace falta repetir. Sin embargo, hacia finales de siglo, en paralelo al decaimiento del impulso revolucionario burgués, las cosas no aparecen tan claras. Las exigencias crecientes de la modernidad, del todo ajenas a los Pereda de turno, agudizan también las contradicciones de quienes pudieron estar más próximos. En la medida respuesta de Galdós a su discurso, en 1897, reencontramos el dualismo en que se debatía la burguesía desde 1868, "con acción simultánea, revolucionaria y conservadora» (Pérez Galdós 33), o desde un plano más personal: «él con sus creencias, yo con mis opiniones» (32). A un lado quedan los restos del optimismo de 1868, que "produjeron forzosamente expansiones del espíritu, mayor desembarazo en las acciones, vuelo más libre en las ideas, marcándose direcciones en cierto modo aventureras, con generosas audacias en algunos casos, con temerarios rumbos en otros» (36). Al lado opuesto de tales «fiebres ardientes» subsiste la tentación del ensimismamiento, «la grave sedación con que vuelve sobre sí misma, y en su propio ser histórico y castizo se encierra» (34). La sociedad «ni quiere lanzarse sin freno al vértigo de las innovaciones, ni estancarse en mohosa rutina» (34). A diferencia de Pereda, Galdós prefiere no discutir la joven literatura, si no es por la velada alusión a «las impaciencias innovadoras» de las que aquel sería «el contrapeso poderoso» (37).

Estamos a un año de 1898 y resulta un sarcasmo, acaso involuntario, la referencia a una Espańa, la de Pereda, que vive «anhelando ser lo que fue» (37). Pero el propio Galdós habla del pasado y no del presente. A esas alturas del desarrollo económico y social de España, el enfrentamiento entre la utópica Arcadia precapitalista y los acomodos de la Restauración, con su bien medido cinismo burgués, iban por otro lado. No era tiempo para estatuas de sal. ¿Quedaba espacio entre lo viejo y las «impaciencias innovadoras»? ¿Estaban fuera las respuestas? Los viejos roles andaban revueltos o simplemente desfasados. Lo tenían más claro que los artistas aquellos burgueses que, ungidos de bendiciones en Lourdes, habrían acudido a París cuando la Exposición de

5. Es lo que Montesinos definió, en un estudio clásico sobre el autor, la novela-idilio. 
1889 para admirar el modernísimo icono industrial de Eiffel ${ }^{6}$. La lucha por la hegemonía cultural parecía resuelta hacia finales de siglo.

La resistencia a lo moderno se confundirá cada vez más con la obsesión por la higiene y la profilaxis. A fin de cuentas, la segunda mitad del siglo está marcada por los descubrimientos de Pasteur sobre las enfermedades infecciosas. La condena de lo nuevo se tiñe así de rasgos patológicos, a los que podía ser más sensible una sociedad naturalmente aprensiva y que sacraliza el ámbito del hogar. No es solamente que esas infecciones vengan de fuera, como sombras errantes a las que nadie llamó, es que lo que mejor define su peligrosidad es la falta de relación con lo propio y asentado. Bajo la coartada de la seguridad, basada en la consanguineidad o en la tradición entendida como cuestión de familia, se combate la amenaza de lo extraterritorial, la capacidad modernista o naturalista para evocar fantasmas eróticos venidos de lugares a la intemperie, expuestos a bacilos o, simplemente, el «estragamiento vicioso» -y al tiempo, fascinante- de urbes como París.

\section{«LA AMOJAMADA CASTIDAD DEL IDIOMA»}

"Mi esposa es de mi tierra; mi querida, de París», escribía Rubén Darío en las palabras liminares a Prosas profanas (1896). Con ello, marcaba una distancia radical frente a la doble moral de los discursos oficiales. El desparpajo erótico de Darío coincide con la expansión de la llamada scientia sexualis en Francia y en Espańa, a partir de $1860^{7}$. El término «sexualidad» aparece en Francia entre 1845 y 1859 , aunque no lo hará en España hasta 1925. No era solamente la teoría microbiana. La obsesión por la sexualidad, especialmente la femenina, es sintomática de una cierta neurosis social que recorre las clases medias, precisamente cuando se exacerba el culto mariano. Visto por el derecho, la resistencia conservadora al influjo francés comulga mal con la proliferación de niñas santas y vírgenes de Lourdes en alabastro que se descuelga desde los Pirineos, tras la proclamación de la Inmaculada Concepción, en 1854. Visto por el revés, la apertura franca y provocadora de Darío hacia lo erótico se corresponde con la aureola canalla de París, tan duradera en el imaginario burgués español.

6. «La sociedad española del último tercio del siglo XIX, con una revolución burguesa prácticamente por hacer, no se hallaba en condiciones de habérselas con un proceso de positivación, del que Francia, país temido por unos y admirado por otros, era el mayor exponente. [...] Esa era la razón última por la que habían autoproclamado a España representante de unas modélicas formas tradicionales de vida que chocaban frontalmente con la modernidad que implicaba el nuevo culto al materialismo científico.» (Caudet 28)

7. «Hacia 1860 se abre la historia contemporánea de la sexualidad. Unos sordos estruendos sacuden la cultura tradicional, el ámbito de la imagen erótica se transforma. Encerrado en la esfera privada, el burgués comienza a sufrir a causa de su moral. El espejismo de una sexualidad popular, brutal y libre, aviva la tentación de la fuga social; el pliegue de sombra de la prostitución se atavía con nuevos atractivos. Zola se convierte en el intérprete de este sufrimiento» (Ariès y Duby 550). 
El tono un tanto guasón con que Valera comenzaba su célebre reseña de $A z u l$, en 1888, incorporaba la inevitable referencia a la infección francesa: «¿Si será este, me dije, uno de tantos y tantos como por todas partes, y sobre todo en Portugal y en la América española, han sido inficionados por Víctor Hugo?» (Valera 104) Y desde las primeras líneas cataloga la obra de «original», o para ser precisos, "de originalidad muy extraña», además de "cosmopolita» (104). En seguida observaremos que el alegado cosmopolitismo es ante todo galicismo, lo cual Valera ni elogia ni censura, con la peregrina excusa de que no es exigible a un nicaragüense el casticismo que se le supone a un español. «Estando así disculpado el galicismo de la mente, es fuerza dar a usted alabanzas a manos llenas por lo perfecto y profundo de ese galicismo; porque el lenguaje persiste español, legítimo y de buena ley, y porque si no tiene usted carácter nacional, posee carácter individual» (107).

Habría que decidir hasta qué punto la aparente simpatía de Valera es coherente con su miopía para distinguir lo auténticamente novedoso en la lírica española de su tiempo y, en consecuencia, hasta qué punto legitima las innovaciones de Darío. Además, ¿̇resultaba suficiente para su admisión en la sociedad literaria hacerlo con un libro cargado de erotismo y precisamente de la mano del señorito trotamundos y libidinoso que para muchos era Valera? A lo largo de la reseńa, aparte de mostrar reticencias sobre los pensamientos «ni muy edificantes ni muy consoladores» (Valera 109), lo que destaca una y otra vez no es tanto el galicismo mental como el erótico, si no eran, de hecho, sinónimos para él ${ }^{8}$. A pesar de ello, lo que se recordará de la reseña será la mil veces citada acusación de galicismo, sin mayores matices.

Diez años más tarde, en 1899, Darío desembarcará en España por segunda vez. Ha publicado en 1896 Prosas profanas y Los raros, obras de madurez. Ya no es el muchachito de $A z u l$, a quien Valera había animado con su sorna habitual y cuyo renombre él supo utilizar. En las crónicas de España contemporánea (1901) el reencuentro ofrece imágenes de una literatura exhausta, donde las viejas figuras «están decaídas, o a punto de desaparecer»e incluso entre los jóvenes poco válido hay «fuera de un soplo que se siente venir de fuera y que entra por la ventana que se han atrevido a abrir en el castillo feudal unos pocos valerosos» (Darío 59-60). La comparación con América latina se le hace inevitable, pues «mal o bien, por obra de nuestro cosmopolitismo y, digámoslo, por la audacia de los que hemos perseverado, se ha logrado en el pensamiento de América una transformación que ha producido, entre mucha broza, verdaderos oros finos» (60). Una frase lo resume: «dentro de las viejas armaduras no cabe hoy más que el aire» (60).

8. En la primera carta traza una expresiva composición de lugar: «Supuse que el autor, nacido en Nicaragua, había ido a París a estudiar para médico o para ingeniero, o para otra profesión; que en París había vivido seis o siete años, con artistas literarios, sabios y mujeres alegres de por allá; y que mucho de lo que sabe lo había aprendido de viva voz, y empíricamente con el trato y roce de aquellas personas» (Valera 105). Empíricamente, dice... El anuncio de La carne, en la cubierta, le tiene «un tufillo de pornografía» (112). 
En muchos pasajes de España contemporánea se vuelve a las comparaciones con París o Buenos Aires. La entrada "El Modernismo» (325-330) es buen ejemplo. En España, salvo en Barcelona, se ignora a los modernistas o se los tilda de homosexuales, en gran parte porque no se lee nada de fuera y, lo que es peor, porque se desconocen otras lenguas. Antes, al constatar cierta superioridad provinciana en un comentario de Pardo Bazán sobre si Hugo habría pretendido emular... ¡a Campoamor!, añadirá: «Por lo general, aquí se compara lo propio con lo extranjero, cuando no con aire de superioridad, con un convencido gesto de igualdad. No se dan cuenta de su estado actual» (239-240).

En suma, de tanto temerse «infecciones», «fecundaciones» o «excitaciones», la imagen final del idioma vendría a ser la de una casta señora que sobrevive malamente a la corrupción de los tiempos. Pérez Galdós, por quien Darío no siente especial simpatía, sería de los pocos que por entonces «contribuyeron más a sostener dignamente la amojamada castidad del idioma» (291). El cruce semántico de castidad y lengua nacional apunta de manera certera al meollo de cuanto vamos viendo. En fin, Pereda («un espíritu fósil») le sirve para un experimento que desnuda la inconsistencia de su patriotismo idiomático: «Hay que leer esa Sotileza que han traducido al francés, hay que leerla en el idioma extranjero para ver lo que queda en el esqueleto, despojada de sus afectaciones de dicción: un colosal y revuelto inventario» (242).

$\mathrm{Si}$ es cierta la imagen triunfal de un Darío que, en esa segunda venida, lleva el modernismo a Espańa, no lo sería menos la respuesta despectiva de la mayoría de los escritores, como él mismo constata. Y atención: no se trataba de una divisoria entre viejos y jóvenes o entre progresistas y reaccionarios. Darío indicaba dos causas, sobre las que habremos de volver, porque apuntan al corazón de la modernidad:

El formalismo tradicional por una parte, la concepción de una moral y de una estética especiales por otra, han arraigado el españolismo que, según D. Juan Valera, no puede arrancarse «ni a veinticinco tirones». Esto impide la influencia de todo soplo cosmopolita, como asimismo la expansión individual, la libertad, digámoslo con la palabra consagrada, el anarquismo en el arte, base de lo que constituye la evolución moderna o modernista. (Darío 325-326)

En 1901, a pesar del nihil obstat de Valera al "galicismo de la mente», reencontramos en Clarín la denuncia de un "galicismo de corazón", que parece apuntar precisamente al fondo moralista, más que formal, señalado por Darío. Aunque Clarín destacase por su conocimiento y aprecio de la literatura francesa contemporánea, su trato con los jóvenes modernistas no fue fácil (Beser; Martínez Cachero) ${ }^{9}$. En una de sus «revistas mínimas», de abril de 1901, escribía:

9. «Pero este "Clarín” anti-modernista por aferrado tercamente a principios casticistas fue, antes de 1899, mucho más atento y comprensivo con las novedades literarias.» (Martínez Cachero 384). 
... pero Darío, más francés que español en todo, hasta ha preferido las prensas de París para su libro, que le publica Garnier. Aunque la cosa va en castellano, a veces hasta bueno, el último capítulo se titula "Certámenes y expositiones», así, con $t$; errata simbólica, pues significa, y parece que no, e1 galicismo de corazón que Darío lleva en las entrañas. (Alas 1036)

La diatriba de Clarín no se queda en el galicismo o en la malicia del "castellano, a veces hasta bueno", sino que recae en el repertorio familiar de lo patológico, como cuando opone «las influencias naturales, sanas, como las de raza, nación, tiempo, etcétera, etcétera» a "enfermizas y violentas sugestiones circunstanciales» (Alas 1036). Es, o bien «ese vicio de sugestión forastera, que es el mayor defecto del señor Darío» (1036), o bien "esa nota cursi del mal francés que tiene inundado el espíritu de Rubén Darío» (1038).

Ya vimos lo del mal francés. Anotemos ahora el significado de la palabra «sugestión», pues reaparecerá con frecuencia. En la edición de 1817, la Academia Española la definía como: «La tentación del demonio en la proposición de algún objeto o acción mala a la imaginación que inclina a consentirla o ejecutarla. Suggestio, instigatio.» Y hasta 2001, mantendrá básicamente esta acepción: «2. f. Idea o imagen sugerida. U. m. en sent[ido] peyor[ativo]. Las sugestiones del demonio.»

Clarín, en la vanguardia de la novela, admirador de Zola - no tanto del teórico-, comprensivo en su día con el raro y moderno Baudelaire, retrocede con el tiempo al casticismo más conservador al enfrentarse con la literatura modernista: «¿No estará expuesta a favorecer esa disolución de lo espańol, de lo castizo, de lo nuestro? Sí lo está y su propaganda, que desde el punto de vista de la noticia, de la información, es excelente, necesita correctivo por otro lado", escribía en 1892 (Martínez Cachero 387). Visto así, no parece tanto «el choque de una cierta modernidad europea, representada en el campo literario por Zola, con una identidad española en busca de sí misma» (Lissorgues 70-71), sino que la bandera, como debiéramos de saber a estas alturas, sirve precisamente para tapar cuanto de profanador tiene esa modernidad. Clarín no es Pereda, pero también a él le sirve el casticismo para protegerse de la franqueza erótica de la gente nueva, de sus juegos sacro-profanos, de su decadentismo, de sus jugueteos con lo religioso, de su anarquismo, de su moralidad a fin de cuentas... No es nacionalismo. No es purismo.

\section{«CONSERVAR LA CASTIDAD DE LA LENGUA CASTELlanA»}

Unamuno es otra cosa, aunque él mismo llegará a experimentar, como los anteriores, su desapego de lo moderno, su desmodernización, digamos. Joven aún, había sido autor de un libro titulado precisamente En torno al casticismo (1895), que comienza por la definición del término: «Castizo deriva de casta, así como casta del adjetivo casto, puro" (Unamuno 2007: 65). He ahí un sesgo insólito del término, la castidad, sobre el que ya acumulamos citas: 
Y si tenemos en cuenta que lo castizo se estima como cualidad excelente y ventajosa, veremos cómo en el vocablo mismo viene enquistado el prejuicio antiguo, fuente de miles de errores y daños, de creer que las razas llamadas puras y tenidas por tales son superiores a las mixtas. (2007: 65)

La endogamia, la falta de cruces con otros pueblos, nos debilita. ¿Quién mejor que Rubén Darío podría subscribirlo? Imágenes de páramo espiritual, de inacción, de cosa muerta, dominan su mirada: «Alguna que otra pedrada agita su superficie tan solo, y a lo sumo revuelve el légamo del fondo y enturbia con fango el pozo» (184). "¿Y qué tiene que ver esto con lo otro, con el casticismo?», se preguntará más adelante, y encuentra la respuesta en «el desquite del viejo espíritu histórico nacional que reacciona contra la europeización» (193), concluye. La ruina de la vieja alma castellana -alguna vez «casta fecunda»- «empezó el día en que, gritando: "mi yo, que me arrancan mi yo", se quiso encerrar en sí» (194).

El libro, con su confluencia de corrientes tan variadas como contradictorias, tiene un valor excepcional para abarcar los síntomas de la crisis de la modernidad. Será la apelación al pueblo y a la intrahistoria frente a los conceptos vistos de nación o de Historia. O el rechazo del ensimismamiento casticista para abocarse al fin a otro ensimismamiento, el del jadentro!, el del ser interior, individual o colectivo. Y todo ello entrecruzado por retazos de Hegel, Taine o Marx ${ }^{10}$. En torno al casticismo liquidaría así el ensimismamiento casticista de la vida durante la Restauración, sí, pero con la finalidad paradójica de fundar un nuevo casticismo moderno, que cristalizará pronto bajo la etiqueta noventayochista.

No perdamos el hilo. Interesa comprobar hasta qué punto la proclama de apertura hacia lo europeo incluye para Unamuno las facetas más innovadoras -y cosmopolitas- de la gente nueva, comenzando por Darío (Metzidakis; Meier; Cano), y hasta dónde llegaban sus límites. Es sabido que Unamuno airea en diferentes momentos su rechazo del modernismo, sobre todo en las facetas más manieristas:

Si el lector examina despacio todos estos fenómenos patológicos de nuestro fin de siècle, a los que hay que añadir un soi disant misticismo de borrachos y morfinómanos, reconocerá que todo ello procede del olvido de la dignidad humana, de la caza por la distinción, del temor a quedar anónimo, del empeño por separarse del pueblo. (2007: 353)

Esto escribe en "La dignidad humana», incluidas las dos expresiones burlonas en francés, y a esto seguirá un alegato aún de fondo marxista contra el pensamiento nietzscheano que culebreaba ya por las cabezas de Azorín o Baroja: «Esto solo prueba que la burguesía desesperada anda a la busca de

10. «No solo fue Unamuno miembro del Partido Socialista, como es sabido, hasta, por lo manos, 1897, sino que en 1894 se declara marxista, escribió en marxista hasta la segunda mitad de 1896 y luchaba todavía por sostenerse en ciertas actitudes neo-marxistas cuando le llegó la crisis de 1897» (Blanco Aguinaga 166). 
un dios que encadene al pueblo trabajador a las máquinas, mientras ella se lanza a alcanzar el "sobre-hombre"» (354). Lo que Unamuno escribe ahí merece atención. No es otra diatriba moralista. Cabe leerlo incluso en clave de modernidad, pues demuestra lucidez para reconocer uno de sus rasgos críticos, como es la escisión que produce entre la dimensión social y la estética, que «se realizó tanto más dolorosamente cuanto más se alienaba el arte de la vida y se retiraba en la intocabilidad de la autonomía completa», aquello que intentaría resolver el surrealismo (Habermas 30).

No obstante, una vez desvanecido el marxismo y cualquier apelación a las clases trabajadoras, su mirada se vuelve irremisiblemente moralista. La prueba está, una vez más, en su desprecio, tan pequeño-burgués, del erotismo. La fiebre erótica era fiebre creadora. Iluminaba la cultura europea del fin de siècle, donde a las indagaciones de Freud se suma la apertura moral que tiñe la pintura simbolista o el Art Nouveau. En este sesgo crucial de lo moderno finisecular, Unamuno no se diferencia mucho de aquellos casticistas que criticaba. No resulta extraño que confiese en más de una ocasión su desagrado con lo francés y con los modos, según él blandos y superficiales, de esa cultura (Unamuno Pérez). En 1899 -y en carta a Darío- señalaba abiertamente su falta de atracción hacia París y lo francés: «Algún día explanaré mi hostilidad, hija de temperamento, hacia lo francés y aun hacia lo latino» (Unamuno 1996: 61).

No es solo eso. Unamuno es radicalmente casto, más que castizo. Como lo será Azorín, aunque sin tantas alharacas. Pero eso afecta a sus opiniones literarias hasta el punto de decir que Les liaisons dangereuses es una muestra... de lujuria:

La peste del sadismo inficiona la literatura francesa, como si no hubiera más realidad que la lujuria. En la típica novela de Laclos llega al proselitismo con la repugnante marquesa de Merteuil. Y avec quel art consommé elle distille et insinue son venin! En nuestros días À rebours, de Huysman, ofrece un ejemplo asqueroso. (2007: 137, n. 2)

A esta luz, no sorprende su distancia afectiva ante Rubén Darío, quien exaltará en sus Cantos la «icarne, celeste carne de la mujer!» o escandalizaría en Prosas al escribir que «su espíritu es la hostia de mi amorosa misa». Los tiempos están cambiando, pero ¿no era preferible el rigor de la vieja Castilla, cuando aún era fecunda?: "El realismo castellano es más sensitivo que sensual, sin refinamientos imaginativos y con fondo casto. Huele a bodegón más que a lenocinio, y cuando cae en extremo, más tira, aun en la obscenidad, a lo grosero que a lo libidinoso» (Unamuno 2007: 136). Está claro.

A pesar de todo, y como corrigiendo a Clarín y a Valera, llegará a disculpar a Darío alegando que, "si parece traducido del francés», en realidad «lo que hace es pensar en americano» (1901: 119). Habría distancia, pero también voluntad para entender la diferencia. No olvidemos que el propio Unamuno representaba la irrupción de la gente nueva en aquel recinto sin aire. Aunque fuese como hermano mayor, profesoral y algo calvinista, representaba también cierto escudo intelectual, europeizante y abierto, muy útil en suma frente a la 
hostilidad de los viejos. Así debía de entenderlo Darío, pese a algún desplante, cuando incluía estas líneas de don Miguel en su España contemporánea:

Hay que levantar voz y bandera contra el purismo casticista, que apareciendo con el simple empeńo de conservar la castidad de la lengua castellana, es en realidad solapado instrumento de todo género de estancamiento espiritual, y lo que es aún peor, de reacción entera y verdadera. Eso del purismo envuelve una lucha de ideas. Se tira a ahogar las de cierto rumbo, haciendo que se las desfigure para vestirlas a la antigua castellana. Se encierra en odres viejos el vino nuevo para que se agrie. (Darío 258) ${ }^{11}$

Unamuno apunta a lo esencial cuando denuncia que, bajo la defensa de la "castidad de la lengua», se enmascara la lucha entre progreso y estancamiento. Sin duda, esto en él suena contradictorio, pero ¿no era la contradicción uno de sus sellos? Castidad aparte, la mentalidad abierta del Unamuno de 1899, se muestra también en la concepción supranacional del idioma, frente al castellanismo. Con acertada imagen insistirá en la necesidad de internacionalizar el «viejo castellano, haciéndolo español», por lo que harán bien los americanos en educarse en París, «porque de allí sacarán, por poco que saquen, mucho más que de este erial» (259). No es poco.

\section{AZORÍN LEGITIMA LAS «EXCITACIONES EXTRAÑAS»}

En el importantísimo ensayo de José Martínez Ruiz «La Generación de 1898", incluido en Clásicos y modernos (1913), reencontramos en poco más de un párrafo los siguientes términos: «fecundación», «influencia extraña», «sugestión extraña», "sugestiones etéreas, casi indefinibles, sutiles» que despiertan «estados psicológicos latentes», «avivamientos de la sensibilidad», «excitación extraña que la fecunde», «fuerte excitante»... (Martínez Ruiz 995 y 996).

Es cierto que la semántica de la infección y la obstetricia ha servido en cuanto vamos viendo para establecer todo tipo de cordones sanitarios, pero aquí se abre una perspectiva diferente. Por lo pronto, quien ha escrito esas líneas se había destacado años atrás entre la gente nueva y, como tal, había recibido las puyas casticistas. Julio Casares, jaún en 1916!, le recordará que «si yo no supiera que el virus de París se puede recibir por correo como la vacuna suiza, afirmaría que nuestro autor estuvo en la capital francesa los tres años que median entre Moratín y Literatura» (Casares 136), es decir, entre 1893 y 1896, cuando la infección apuntaba a epidemia. Pero ni siquiera el Azorín coetáneo se libra del baldón «de incurrir en ese estilo asmático, de las frasecitas cortadas» (179-180). Durante un buen número de páginas, y aún de capítulos, Casares le pasa lista de cuantos galicismos -supondría él- debieran de avergonzar a un autor que ahora presumía de castizo y amante de las tradiciones.

11. «Contra el purismo», de Unamuno, artículo al que corresponde la cita de Darío, había aparecido en El Sol, de Buenos Aires, el 24 de octubre de 1899. 
A fin de cuentas, como vamos confirmando, las críticas a la corrupción del lenguaje o al galicismo son la excusa para atacar aquel fondo de ideas malsanas con aromas de decadentismo, naturalismo, positivismo, materialismo o cualquier sinónimo de corrupción o infección. Aunque a Azorín resultaba difícil atacarlo por la vertiente erótica y a Casares solamente le quedaba denunciar «el pesimismo panteísta que él mismo va irradiando» (Casares 190). Pues bien, aquel Azorín de 1913, que había dejado atrás el anarquismo y el monóculo para ejercer de discreto conservador, saltará a la palestra para defender la «aireación del propio intelecto». Lo hace con el léxico visto. Y lo más importante, lo hace frente a la tradicional cerrazón de sus correligionarios.

En la literatura española la generación de 1898 representa un renacimiento. [...] Un renacimiento es sencillamente la fecundación del pensamiento nacional por el pensamiento extranjero. Ni un artista ni una sociedad de artistas podrán renovarse -ser algo- o renovar el arte sin una influencia extraña. Nada hay primero, espontáneo o incausado en arte; aun los artistas que parecen más originales (por ejemplo, en pintura, un Velázquez o un Goya) deben toda su fuerza, todo su vigor, toda su luminosidad a una sugestión extraña a ellos. No se trata de imitaciones o rapsodias; las influencias de que hablamos son sugestiones etéreas, casi indefinibles, sutiles, que hacen despertar en el artista estados psíquicos latentes y determinan avivamientos de la sensibilidad que, sin esas sugestiones, acaso no hubiera sido tan intensa o quizá no hubiera sido de ese modo. La vida intelectual de un pueblo necesita una excitación extraña que la fecunde. (Martínez Ruiz 995)

Habrá que estar atentos a los malabarismos verbales de este Azorín para encauzar sus fiebres juveniles $-\mathrm{y}$ no solo las suyas- hacia una relectura de su evolución ${ }^{12}$. Con cuidado, diluye el «espíritu de protesta, de rebeldía» de la generación, que no habría protagonizado una ruptura, atención, sino un renacimiento (998). Un renacimiento, advierte, es la fecundación de lo nacional por lo extranjero. Por ahí discurre la parte más interesante de la argumentación del Azorín posterior a 1902, empeñado en integrar en el imaginario conservador «las influencias extranjeras» (1009) o, simplemente, la «influencia extraña» (1010). Al aderezar su propia imagen, la quiere también congruente.

Las traiciones veladas del lenguaje están presentes, no obstante, en las vueltas de tuerca sobre el viejo léxico. Lo que antes sonaba a amenaza, a contaminación, incluso a violencia sexual, suena ahora con cierta sensualidad agazapada, como esa «excitación» junto a "fecundación», y todo ello sutil, etéreo, casi imperceptible, como un perfume en el aire.

12. Inman Fox (1989: 1764), entre otros, ha señalado cómo este «método historiográfico obedeció a la ideología, y hasta el discurso, de un programa político», el de Juan de la Cierva, «uno de los jefes del partido conservador en que Azorín militaba entre 1905 y 1923». De 1913 es también la referencia del joven Ortega y Gasset a una «generación fantasma» de 1898, «históricamente espúrea», que espoleó la respuesta de Azorín (Conard 470). 


\section{EPÍLOGO: LOS LÍMITES DE LO MODERNO}

Veintitantos años más tarde, Pedro Salinas hace su relectura de este último artículo y propone la escisión de la "generación del 98" como un "conflicto entre dos espíritus». Es suficientemente conocida y me interesa ahora solo en cuanto estrategia discursiva. Donde Azorín modelaba la evolución ideal de un mismo grupo, Salinas enfrentará dos universos irreconciliables: «El Modernismo, tal como desembarcó imperialmente en España personificado en Rubén Darío y sus Prosas profanas, era una literatura de los sentidos, trémula de atractivos sensuales, deslumbradora de cromatismo» (Salinas II, 210). ¡Trémula de atractivos sensuales! Sin duda, se han desatado los fantasmas eróticos del siglo anterior. "Lo nuevo, lo modernista es el apetito de los sentidos...» Pero atención, porque esa invasión de lujuria se topará con el cilicio de la enjuta Castilla inventada por el vasco Unamuno. ¿Y dónde quedaba la modernidad? El 98 quedaba listo para su versión fascista, de manos del joven Laín Entralgo.

Poco después, en el oscuro 1948 español, Dámaso Alonso aún recuperará términos parecidos para la nueva bête noire, el surrealismo: «reacción similar ante excitantes externos» (Alonso 168), "por fuera bulle el surréalisme», "emanaciones difusas de eso que está en el aire» (173)... Dejémoslo aquí. El muestrario anterior está lejos de ser exhaustivo y faltan referencias imprescindibles a Espronceda, o a los «suspirillos germánicos» de Bécquer, o a las cuestiones de género, por poner algún ejemplo. ¿No habían censurado los primeros editores de las Rimas la 55, «Una mujer me ha envenenado el alma»?

Recuerdo, con todo, que nuestro objetivo era otro. Bajo el reparto de etiquetas de espańolidad, basadas en la pureza del lenguaje o el acomodo con la tradición, subyace una lectura ideológica que fija de hecho lo admisible dentro de lo moderno. Salvo en el caso de los más conservadores, es difícil establecer pautas de edad o políticas. El tono y los modos de los discursos casticistas traicionan un fondo subconsciente de imágenes de obscura sexualidad, de infecciones larvadas, de impulsos primarios, genesíacos, al mismo tiempo tentadores y peligrosos. Entran en ese catálogo, al margen del obvio plano religioso, lo sexual, la indagación en lo feo y oscuro, el rechazo del anarquismo dariano -no solo formal- o el desagrado ante lo hermético o lo demasiado abierto. La vuelta al orden parece en España un principio sagrado.

Y aún queda el provincianismo. Cuando la novedad resulta integrable, se dirá que siempre estuvo aquí, como demostraría el realismo esencial de la literatura española o como hará Alberti poco después, al vender cuchufletas andaluzas como imágenes surrealistas. Rubén Darío, en cita vista, lo resumía cuando apuntaba como última causa, más allá del «formalismo tradicional» español, «la concepción de una moral y de una estética especiales». Esa cerrazón es algo más profundo que la negación de "todo soplo cosmopolita», pues afecta a «la expansión individual, la libertad», aquella que rompe corsés morales. $\mathrm{Y}$ lo moderno, resume Darío, es «el anarquismo en el arte». Esa es la «base de lo 
que constituye la evolución moderna o modernista» (Darío 325-326) y esos vendrían a ser los límites de la modernidad.

Por supuesto, hay grandes excepciones, desde el cinismo erótico de Bradomín hasta el salto a lo hondo de Juan Ramón Jiménez. No obstante, batalla tras batalla, se diría que los modernos acaban sucumbiendo al ensimismamiento melancólico, recogiéndose en lo familiar-si no castizo-, vencidos por la inercia e incapaces de profanar las últimas fronteras de la moral burguesa, «las pautas de moralidad y la utilidad» que cita Habermas ${ }^{13}$.

\section{Bibliografía}

Alas L., «Clarín», 2002, Obras completas, X, ed. J.-F. Botrel e Y. Lissorgues, Oviedo, Nobel.

Alonso D., 1988, "Una generación poética (1920-1936)», en Poetas españoles contemporáneos, $3^{\mathrm{a}}$ ed., Gredos, Madrid, 155-177.

Álvarez Junco J., 2001, Mater dolorosa. La idea de España en el siglo XIX, Madrid, Taurus.

Ariès Ph. y G. Duby, dirs., 1991, Historia de la vida privada. VIII: Sociedad burguesa, Madrid, Taurus.

Beser S., 1968, Leopodo Alas, crítico literario, Madrid, Gredos.

Blanco Aguinaga C., 1966, «El socialismo de Unamuno: 1894-1897», Revista de Occidente, 41, 166-184.

Cano J. L., 1997, «Rubén y Unamuno», Anthropos, 170, 137.

Carnero G., 1978, Orígenes del romanticismo reaccionario español: el matrimonio Böhl de Faber, Valencia, Universidad.

Casares J., 1916, Crítica profana (Valle-Inclán, “Azorin”, Ricardo León), Imprenta Colonial, Madrid.

Caudet F., 2002, El parto de la Modernidad. La novela española de los siglos XIX y XX, Madrid, Ediciones de la Torre.

Conard P., 1967, «Ortega y Gasset, écrits politiques (1910-1913)», Mélanges de la Casa de Velázquez, 3, 417-475.

Darío R., 2013, España contemporánea, ed. N. Rivas Bravo, Sevilla, Renacimiento.

Ferrari E., 1905, Discursos leídos ante la Real Academia Española en la recepción pública de D. Emilio Ferrari el día 30 de abril de 1905, Madrid.

Fox I., 1989, «El concepto de la generación de 1898 y la historiografía literaria», en A. Vilanova, ed., Actas del X Congreso de la Asociación de Hispanistas, II, Barcelona, PPU, 1761-1770.

Fox I., 1997, La invención de España. Nacionalismo liberal e identidad nacional, Madrid, Cátedra.

13. Este trabajo se ha realizado en el marco del grupo de investigación HISPANIA (G000208) de la Universidade da Coruña, subvencionado por la Xunta de Galicia (GPC-2015/028). Agradezco al Centre de Recherche sur l'Espagne Contemporaine XVIII ${ }^{e}-\mathrm{XIX}^{\mathrm{e}}$-XX ${ }^{\mathrm{e}}$ siècles (CREC), de París 3, y a sus responsables, su invitación y las facilidades dadas durante el mes de abril de 2016 para su elaboración. 
Freyre de Castrillón M., 1809, Remedio y preservativo contra el mal francés de que adolece parte de la nación española, Valencia.

Habermas J., 1985, «La modernidad, un proyecto incompleto», en H. Foster, ed., La posmodernidad, Barcelona, Kairós, 19-36.

Hobsbawm E., 1991, Naciones y nacionalismo desde 1780, Barcelona, Grijalbo Mondadori.

Lissorgues Y., 1997, «La obra de Emilio Zola como revelador de la singularidad literaria y filosófica española», en S. Saillard y A. Sotelo Vázquez, eds., Zola y España. Actas del Coloquio Internacional, Lyon (1996), Barcelona, Universitat, 69-79.

Litvak L., 1977, "La idea de la decadencia en la crítica antimodernista en España (1888-1910)», Hispanic Review, 45:4, 397-412.

López M., 1979, «Los escritores de la Restauración y las polémicas literarias del siglo XIX en España», Bulletin Hispanique, 81:1-2, 51-74.

Martínez Cachero J. M., 1983, "La actitud antimodernista del crítico Clarín», Anales de Literatura Española, 2, 383-398.

Martínez Ruiz J., «Azorín», 1999, Obras escogidas, II, 2ª ed., coord., M. A. Lozano Marco, Madrid, Espasa-Calpe.

Meier E., 1983, "Unamuno, Rubén Darío y el Modernismo», Cuadernos de la Cátedra Miguel Unamuno, 27-28, 135-148.

Metzidakis Ph., 1960, "Unamuno frente a la poesía de Rubén Darío», Revista Iberoamericana, 25:50 (julio-diciembre), 229-249.

Montesinos J. F., 1961, Pereda o la novela idilio, México, El Colegio de México.

Pereda J. M. de, 1897, Discursos leidos ante la Real Academia Española en la recepción pública del Sr. D. José María de Pereda el domingo 21 de febrero de 1897, Madrid.

Pérez Galdós, B., 1897. Vid. Pereda, J. M. de, 1897.

Salinas P., 1983, «El concepto de generación literaria aplicado a la del 98» y «El problema del modernismo en España, o un conflicto entre dos espíritus», en Ensayos completos, ed. S. Salinas, 3 vols., Madrid, Taurus, I, 93-98; II, 208-218.

Unamuno M. de, 1901, «España contemporánea, por Rubén Darío, París, 1901», La Lectura, 118-119.

Unamuno M. de, 1996, Epistolario americano (1890-1936), ed. L. Robles, Salamanca, Universidad.

Unamuno M. de, 2007, Obras completas, VIII, ed. R. Senabre, Madrid, Fundación J. A. de Castro (Biblioteca Castro).

Unamuno Pérez M. de la C. de, 1991, Miguel de Unamuno y la cultura francesa, Salamanca, Universidad.

Valera J., 1995, "A D. Rubén Darío», en Rubén Darío, Azul... Cantos de vida y esperanza, ed. J. M. Martínez, Madrid, Cátedra, 103-122. 